\title{
TGA INVESTIGATION OF CO2 GASIFICATION OF HYDROTHERMALLY TREATED BIOMASS (CORN COB - COCONUT SHELL MIXTURE)
}

\author{
Ahmad T. Yuliansyah ${ }^{1 *}$, Chika O. Putri ${ }^{1}$, Britania D. Clarasinta ${ }^{1}$, Moriyasu Nonaka ${ }^{2}$ \\ ${ }^{I}$ Department of Chemical Engineering, Faculty of Engineering, Universitas Gadjah Mada, \\ Jln. Grafika No. 2 Yogyakarta 55281, Indonesia \\ ${ }^{2}$ Department of Earth Resources Engineering, Faculty of Engineering, Kyushu University, \\ 744 Motooka, Nishi-Ku, Fukuoka 819-0395, Japan
}

(Received: August 2019 / Revised: October 2019 / Accepted: October 2019)

\begin{abstract}
Gasification is one option for producing cleaner fuel from biomass. A gaseous mixture of $\mathrm{H}_{2}$, $\mathrm{CO}, \mathrm{CH}_{4}$, and $\mathrm{CO}_{2}$ is produced through the partial oxidation of biomass with a gasifying agent such as air, pure $\mathrm{O}_{2}$, steam, $\mathrm{CO}_{2}$, or a mixture of these. This method is capable of handling a wide range of inhomogeneous biomass (including forest, agricultural, and organic processing residues) and converting them into a homogeneous gas with a considerably higher level of applicability. In this research, the $\mathrm{CO}_{2}$ gasification of hydrothermally treated biomass has been studied using TGDTA analyzer (Bruker TG DTA 2000SA) apparatus. The biomass treated was a mixture of corn cob and coconut shell (weight ratio of 1:1). This raw biomass was firstly subjected to hydrothermal treatment at three different temperatures $\left(200,240\right.$, and $270^{\circ} \mathrm{C}$-denoted as $\mathrm{H}-200$, $\mathrm{H}-240$, and $\mathrm{H}-270$ ) using a batch autoclave prior to being gasified by $\mathrm{CO}_{2}$ under atmospheric pressure in the TGA apparatus. The experimental results show that the weight loss of hydrochar was resulted mostly from the process of devolatilization $(82.92-86.16 \%)$. Hydrochar obtained from higher hydrothermal temperatures demonstrated a lower reactivity of gasification, due to the lower amount of moisture and volatile matter. In addition, higher-temperature hydrochar contained lower potassium content and thus shifted the conversion of gasification reaction to a higher temperature.
\end{abstract}

Keywords: Coconut shell; Corn cob; $\mathrm{CO}_{2}$ gasification; Hydrothermal treatment; Reactivity

\section{INTRODUCTION}

The rapid development of the industry and transportation sector has boosted the need for energy. However, there has been a steady decrease in the supply of energy derived from fossil fuels such as coal, petroleum, and natural gas. This is taking place alongside growing concern for environmental matters such as the effects of greenhouse gases, acid rain, and global warming, which are associated with large emissions of $\mathrm{CO}_{2}, \mathrm{NO}_{\mathrm{x}}$, and $\mathrm{SO}_{\mathrm{x}}$ from the ongoing use of fossil fuels. Thus, the search for alternative energy sources that are more environmentally friendly has become a critical issue worldwide. For this reason, more attention is being paid to the exploration of renewable energy, especially biomass, which offers the greatest potential (Mangut et al., 2006).

Gasification offers a potential means of producing cleaner fuel from biomass. A gaseous mixture of $\mathrm{H}_{2}, \mathrm{CO}, \mathrm{CH}_{4}$, and $\mathrm{CO}_{2}$ is produced through the partial oxidation of biomass with a gasifying agent such as air, pure $\mathrm{O}_{2}$, steam, $\mathrm{CO}_{2}$, or a mixture of these. This method is able to handle a wide

\footnotetext{
*Corresponding author's email: atawfieq@ugm.ac.id, Tel. +62-274-6492171, Fax. +62-274-555320 Permalink/DOI: https://doi.org/10.14716/ijtech.v10i6.3641
} 
range of inhomogeneous biomass (including forest, agricultural, and organic processing residues) and convert them into a homogeneous gas with a considerably higher level of applicability. Depending on its composition, the gas product can be used to generate heat and power (as fuel) (Sridhar et al., 2001; Yin et al., 2002; Rodrigues et al., 2003), to produce $\mathrm{H}_{2}$ (Wei et al., 2008; Tavasoli et al., 2009; Acharya et al., 2009; Demirbas, 2009;), or to synthesize various chemicals and liquid fuels (Tijmensen et al., 2002; Datar et al., 2004).

There are many factors that influence the characteristics of biomass gasification, two of which are the biomass type and pre-treatment method. Different types of biomass, with their characteristically wide-ranging component compositions, vary in their gasification reactivity from one to another (Kumar \& Gupta, 1994; Moilanen et al., 2009). Attempts have been made to use many different biomass samples as feedstock for gasification, including rice husk (Gibran et al., 2018) and oil palm frond (Sulaiman et al., 2012). However, raw biomass usually has a low energy density, high moisture content, and high $\mathrm{O} / \mathrm{C}$ ratio, leading to lower gasification efficiency. The optimum temperature for raw biomass gasification is below $700^{\circ} \mathrm{C}$, much lower than the temperature of gasification in practice. Meanwhile, choking and blockage of the gasifier are two commonly occurring problems due to the formation of condensable tar from biomass (Prins et al., 2006). Therefore, it would be advantageous for the biomass to be treated prior to gasification. Much work has been conducted in the area of dealing with biomass preparation; however, most of it employed pyrolysis (Chen et al., 1992; Kumar et al., 1992; Cetin et al., 2005) or torrefaction (Prins et al., 2006; Couhert et al., 2009) as a pre-treatment method. To our knowledge, only a few publications have provided information on the application of hydrothermal treatment as a feedstock preparation method for biomass gasification. Hence, the effect of hydrothermal pre-treatment on the $\mathrm{CO}_{2}$ gasification of biomass was investigated in this study. A mixture of corn cob and coconut shell was hydrothermally treated in the range of 200-270 ${ }^{\circ} \mathrm{C}$ using a batch autoclave, and subsequently gasified by $\mathrm{CO}_{2}$ under atmospheric pressure in TGA apparatus.

\section{METHODS}

\subsection{Materials}

Raw corn cob and coconut shell were collected from local farmers in Indonesia. Each type of raw biomass was then ground and pulverized (to reduce its particle size) separately to facilitate homogeneous mixing and enhance its effective conversion to hydrochar under hydrothermal treatment. Only biomass with $-20+32$ mesh particle size was used as feedstock for the hydrothermal process.

\subsection{Experimental Procedure}

The biomass feedstock for hydrothermal treatment was prepared by blending equal amounts of corn cob and coconut shell. Approximately $15 \mathrm{~g}$ of this biomass sample was then mixed with 150 $\mathrm{mL}$ of aquadest to form a slurry that was fed into the hydrothermal reactor. The reactor used was the same apparatus as that employed in our previous work (Mappapa \& Yuliansyah, 2018). Briefly, the reactor system consisted of a batch-type autoclave, electric heater, and stirrer. In addition, it was equipped with a temperature controller and pressure sensor. The hydrothermal treatment was conducted at three different temperatures $\left(200,240\right.$, and $\left.270^{\circ} \mathrm{C}\right)$. For each targeted temperature, the reaction was maintained for a 30-min residence time, and the slurry was cooled down afterward. After filtration and oven-drying, the hydrochar products were obtained (the products were called $\mathrm{H}-200, \mathrm{H}-240$, and $\mathrm{H}-270$ ). The $\mathrm{CO}_{2}$ gasification behavior of the product was further investigated using TG-DTA analyzer (Bruker TG DTA 2000SA) apparatus. The $\mathrm{CO}_{2}$ gasification process was conducted in 2 consecutive steps, i.e., charring and gasification. Approximately $15 \mathrm{mg}$ of the hydrochar product was placed in a balance room and heated in $\mathrm{He}$ gas (flow rate: $100 \mathrm{~cm}^{3} / \mathrm{min}$ ) at a heating rate of $30^{\circ} \mathrm{C} / \mathrm{min}$, from the ambient temperature to 
$1200^{\circ} \mathrm{C}$ for charring. Afterward, it was cooled down to $600^{\circ} \mathrm{C}$ and held for $10 \mathrm{~min}$ at this temperature. A non-isothermal gasification test of the char was then performed in a flow of $\mathrm{He}$ and $\mathrm{CO}_{2}$ at a heating rate of $10^{\circ} \mathrm{C} / \mathrm{min} . \mathrm{CO}_{2}$ as a gasifying agent was introduced to the furnace immediately before the balance room. The addition of $\mathrm{CO}_{2}$ was carried out at the rate of 100 $\mathrm{cm}^{3} / \mathrm{min}$; therefore, the total gas flow rate of the $\mathrm{He}$ and $\mathrm{CO}_{2}$ mixture was $200 \mathrm{~cm}^{3} / \mathrm{min}$.

\subsection{Analysis}

The hydrochar obtained from the hydrothermal treatment process was characterized by calorific value, proximate, and ultimate analysis. In addition, the potassium content of the hydrochar was determined using Inductively Coupled Plasma (ICP) equipment to evaluate its effect on the gasification process. Three other important parameters for biomass-derived fuel are defined as follows (Lestari et al., 2018):

$$
\begin{gathered}
\text { Mass yield, } \%=\frac{\text { mass of dried hydrochar }}{\text { mass of dried biomass sample }} \times 100 \% \\
\text { Energy densification ratio }(E D R)=\frac{\text { gross calorific value of hydrochar }}{\text { gross calorific value of biomass sample }} \\
\text { Energy yield }=\text { Mass yield } x \text { EDR }
\end{gathered}
$$

The performance of the $\mathrm{CO}_{2}$ gasification was investigated by evaluating the TG plot of differential weight changes of the hydrochar sample versus the elapsed time and temperature.

\section{RESULTS AND DISCUSSION}

The quality of biomass was found to have improved after undergoing hydrothermal treatment, as represented by the increase in calorific value. Proximate analysis was conducted to measure quality based on important fuel parameters such as moisture content, ash content, volatile matter, and fixed carbon. As shown in Table 1, the temperature had an effect on the property of the hydrochar. Changes in some of the chemical bonds in the biomass structure resulting from hydrothermal decomposition reactions led to an increase in the content of fixed carbon. At the same time, there was a reduction in the moisture and volatile matter content, as hydrothermal temperature increased.

Table 1 Fuel properties of hydrochar of corn cob and coconut shell mixture

\begin{tabular}{lrrr}
\hline \multicolumn{1}{c}{ Analysis Item } & $\mathrm{H}-200$ & $\mathrm{H}-240$ & $\mathrm{H}-270$ \\
\hline Ultimate Analysis (wt.\%, dry basis) & & & \\
$\mathrm{C}$ & 52.74 & 53.70 & 53.01 \\
$\mathrm{H}$ & 5.92 & 5.85 & 5.83 \\
$\mathrm{~N}$ & 0.23 & 0.20 & 0.23 \\
O* & 41.11 & 40.25 & 40.93 \\
Proximate analysis (wt.\%) & & & \\
Moisture content & 4.21 & 3.08 & 3.10 \\
Volatile matter & 80.61 & 77.23 & 75.64 \\
Fixed carbon & 14.84 & 15.69 & 18.40 \\
Ash & 0.85 & 4.00 & 2.86 \\
Potassium content $(\mathrm{mg} / \mathrm{kg})$ & 908.86 & 520.68 & 671.75 \\
Gross calorific value $(\mathrm{MJ} / \mathrm{kg})$ & 19916 & 20669 & 21422 \\
\hline
\end{tabular}

*) calculated by difference 
As shown in Table 1, the proportion of fixed carbon gradually increased from 14.84 to 18.40 wt. $\%$, while the volatile matter fell from 80.61 to $75.64 \mathrm{wt} . \%$, when the biomass sample was hydrothermally treated from 200 to $270^{\circ} \mathrm{C}$. As a result, the calorific value increased from 19916 to $21422 \mathrm{MJ} / \mathrm{kg}$. This value is comparable with that of typical Indonesian low-rank coal, such as that used by Parshetti and his co-workers (2014). Treatment at a higher temperature also produced hydrochar with a lower potassium content since there was greater leaching of potassium into the aqueous medium. The potassium contents of the hydrochars $(520.68-908.86 \mathrm{mg} / \mathrm{kg})$ were much lower in comparison to those of the parent biomass (4222.50 and $3206.66 \mathrm{mg} / \mathrm{kg}$ for corn cob and coconut shell respectively). This result aligns well with that obtained in a study by other researchers (Ruksathamcharoen et al., 2018). Since the potassium content corresponds to the tendency for combustion facilities to promote slagging and fouling, it is suggested that the resulting hydrochar shows potential as a feedstock for gasification.

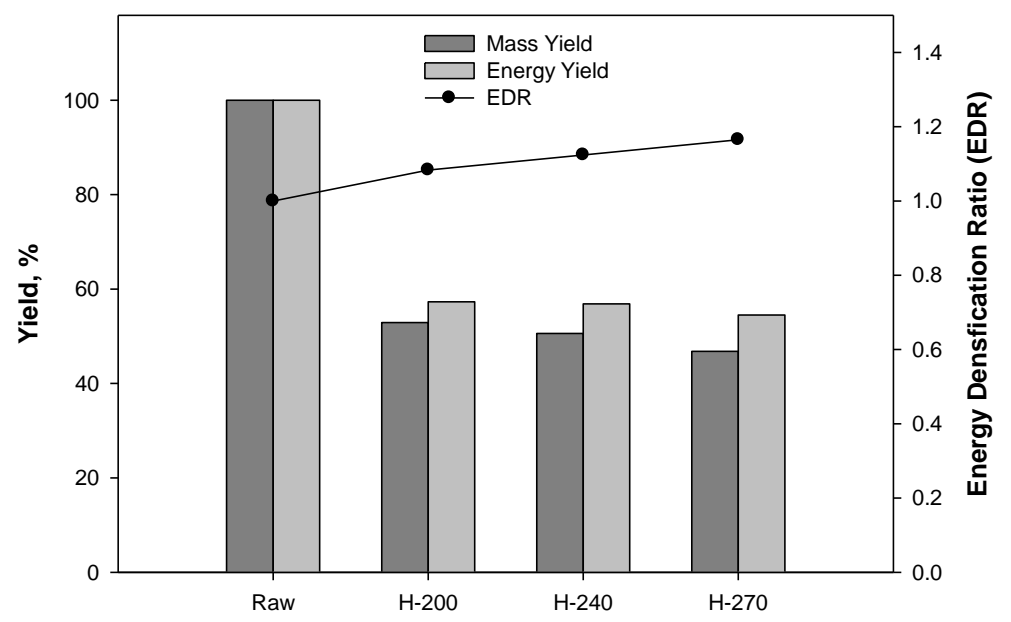

Figure 1 Mass yield, energy yield, and energy densification ratio of hydrochars

Figure 1 shows the mass yield, energy yield, and energy densification ratios of the hydrochars obtained from different temperature treatments, in comparison with the raw biomass. Progressive decomposition reactions under hydrothermal conditions meant the recovered solid (as hydrochars) was only approximately $\sim 50 \mathrm{wt} \%$. A slight decrease in mass yield was observed within the range $200-270^{\circ} \mathrm{C}$. However, the decrease in mass yield was balanced by the increase in calorific value. As a result, the energy densification ratio increased in line with the increase in temperature. As shown in Figure 1, the energy yield of hydrochars also fell slightly within the range $200-270^{\circ} \mathrm{C}$. The energy yields for $\mathrm{H}-200, \mathrm{H}-240$, and $\mathrm{H}-270$ were $57.29,56.87$, and $54.52 \%$, respectively.

The data in Table 1 show that all hydrochar products still have relatively highly volatile matter. Thus, in this experiment, the charring process was conducted first in order to optimize the biomass conversion in the subsequent step $\left(\mathrm{CO}_{2}\right.$ gasification). The reaction of the char and $\mathrm{CO}_{2}$ under gasification step takes place according to Equation 4 (Kajita et al., 2010).

$$
\mathrm{C}+\mathrm{CO}_{2} \rightarrow 2 \mathrm{CO}
$$




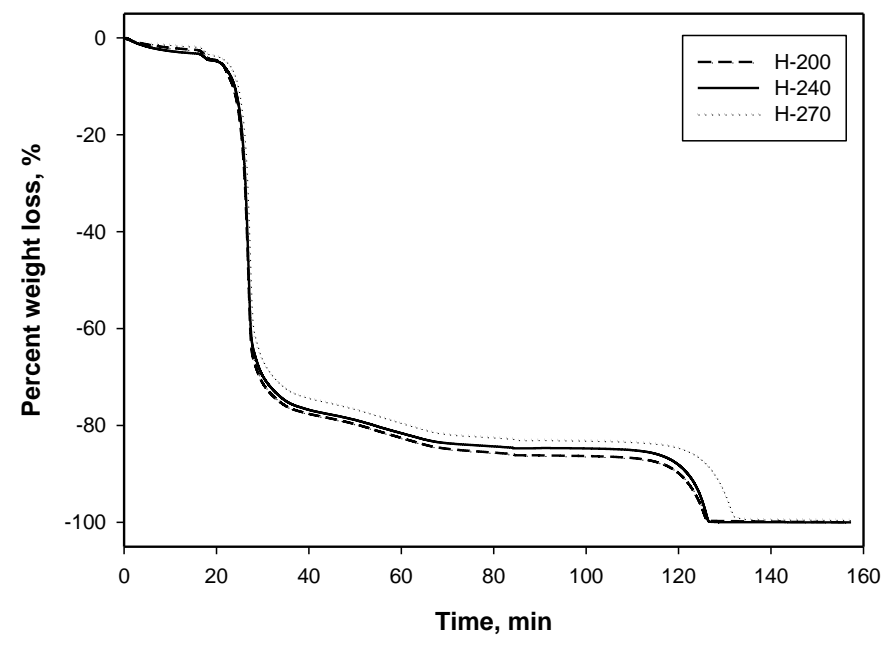

Figure 2 Percent weight loss curve of $\mathrm{CO}_{2}$ gasification

Figure 2 shows a plot of the percent weight loss vs. time for hydrochar products. It suggests that the temperature of the hydrothermal treatment has an effect on weight loss behavior. Hence, hydrochar resulting from treatment at a higher temperature has lower reactivity, as indicated by the delayed time of reaction (relative to that of lower temperature). The curve thus shifts to the right, as the hydrothermal temperature increases. This shift might also potentially be caused by the lower potassium content, which has a catalytic effect on gasification reaction (Asadullah et al., 2010).

A typical TG analysis of the $\mathrm{CO}_{2}$ gasification of hydrochar is presented in Figure 3. The figure contains a plot of the temperature, percent weight loss, and weight loss rate versus elapsed time for the $\mathrm{H}-270$ sample. In general, the plot can be split into 2 segments, i.e., the charring and $\mathrm{CO}_{2}$ gasification steps. In regard to the plot of the weight loss rate, 3 peaks appeared - denoted as peaks A, B, and C. Peaks A and B denote the drying and pyrolysis taking place in the charring step, while peak $\mathrm{C}$ indicates the gasification reaction by $\mathrm{CO}_{2}$. Moisture was removed from the sample during the drying process (around $100^{\circ} \mathrm{C}$ ), while the volatile matter was removed during the pyrolysis process. The partial weight loss in both segments for all hydrochar samples is tabulated in Table 2.

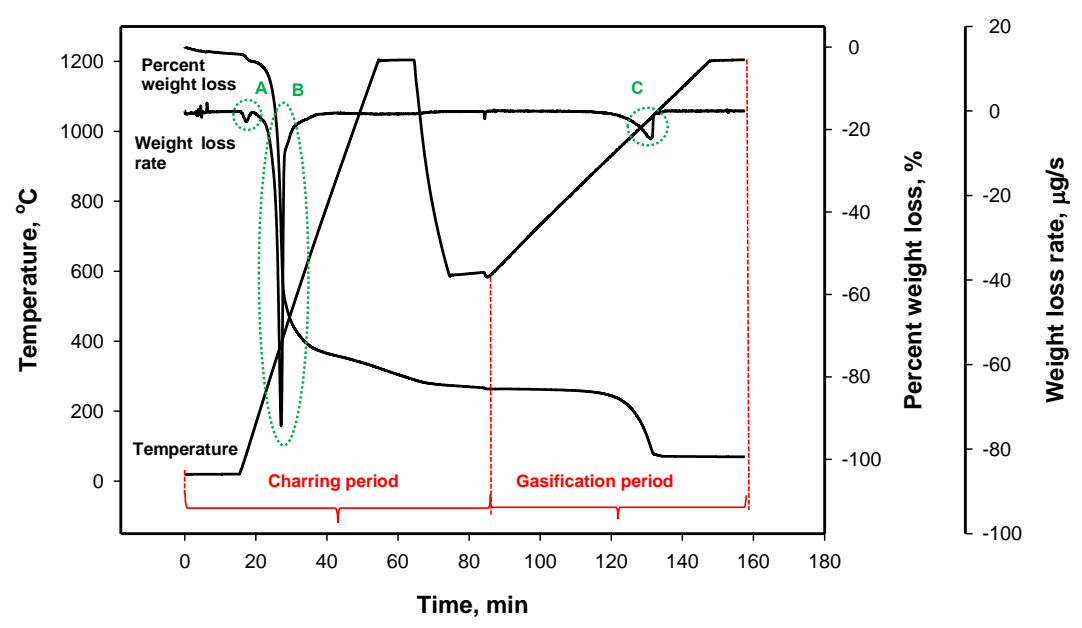

Figure 3 Typical TG analysis of $\mathrm{CO}_{2}$ gasification 
Table 2 Fractional weight loss during the charring and the gasification steps

\begin{tabular}{ccc}
\hline \multirow{2}{*}{ Sample } & \multicolumn{2}{c}{ Partial weight loss (\%) } \\
\cline { 2 - 3 } & Charring & Gasification \\
\hline H-200 & 86.15 & 13.85 \\
H-240 & 84.71 & 15.29 \\
H-270 & 82.92 & 16.47 \\
\hline
\end{tabular}

The data in Table 2 indicate that $82.92-86.16 \%$ of the weight of the hydrochar was eliminated during the charring step. This corresponds to the total content of moisture and volatile matter of the hydrochar. H-200, which had the highest content of moisture and volatile matter, exhibited the strongest charring reaction. Only $13.85 \%$ of the initial sample amount remained and was promoted for $\mathrm{CO}_{2}$ gasification.

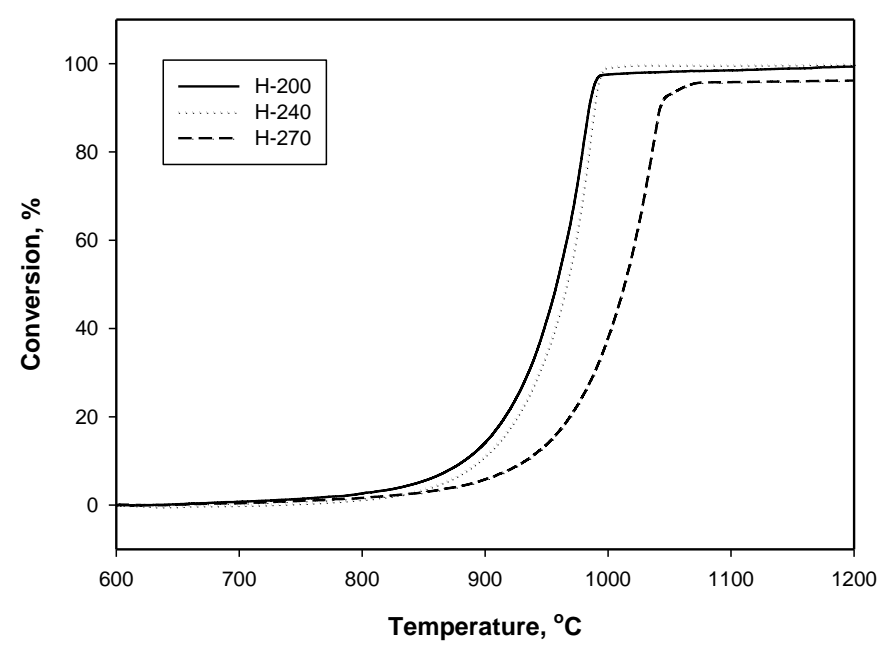

Figure 4 Conversion of $\mathrm{CO}_{2}$ gasification of hydrochar

Figure 4 illustrates the conversion of $\mathrm{CO}_{2}$ gasification of hydrochar, relative to the amount of charred sample. It can obviously be seen that the reactivity of hydrochar decreases in line with the increasing hydrothermal temperature. For instance, 50\% conversion of charred H-270 was achieved when the gasification temperature reached $1013^{\circ} \mathrm{C}$, which was much higher than that for both $\mathrm{H}-200\left(958^{\circ} \mathrm{C}\right)$ and $\mathrm{H}-240\left(966^{\circ} \mathrm{C}\right)$. The declining reactivity was caused by the formation of a large aromatic ring system that was deposited on the char surface, leading to a decrease in the number of active sites available for gasification reaction (Kumar \& Gupta, 1994; Asadullah et al., 2010).

\section{CONCLUSION}

Although biomass is a clean and renewable fuel for gasification, it is not ideal for use in a gasifier due to its low content of fixed carbon and high moisture and volatile matter content. Hydrothermal treatment can reduce the volatile matter content of biomass which tends to form tar in the subsequent gasification process. However, the increased temperature of hydrothermal treatment leads to a decrease in the reactivity of gasification. Since the moisture and volatile matter contents of hydrochar are still relatively high (moisture content of 3.08-4.21\% and volatile matter content of 75.64-80.61\%), the overall process was dominated by devolatilization. Only 13.85-16.47 wt.\% of hydrochar was converted through gasification by $\mathrm{CO}_{2}$. 


\section{ACKNOWLEDGEMENT}

The authors gratefully thank the Department of Chemical Engineering, Faculty of Engineering, Universitas Gadjah Mada for the funding of this research. In addition, the partial financial support from AUN SEED Net/JICA through the Short Term Research Program in Japan is highly acknowledged.

\section{REFERENCES}

Acharya, B., Dutta, A., Basu, P., 2009. Chemical-looping Gasification of Biomass for Hydrogenenriched Gas Production with In-process Carbon Dioxide Capture. Energy \& Fuels, Volume 23(10), pp. 5077-5083

Asadullah, M., Zhang, S., Min, Z., Yimsiri, P., Li, C.Z., 2010. Effects of Biomass Char Structure on its Gasification Reactivity. Bioresource Technology, Volume 101(20), pp. 7935-7943

Cetin, E., Gupta, R., Moghtaderi, B., 2005. Effect of Pyrolysis Pressure and Heating Rate on Radiata Pine Char Structure and Apparent Gasification Reactivity. Fuel, Volume 84(10), pp. $1328-1334$

Chen, G.X., Sjostrom, K. Bjornbom, E., 1992. Pyrolysis/Gasification of Wood in a Pressurized Fluidized Bed Reactor. Industrial \& Engineering Chemistry Research, Volume 31(12), pp. 2764-2768

Couhert, C., Salvador, S., Commandre, J.M., 2009. Impact of Torrefaction on Syngas Production from Wood. Fuel, Volume 88(11), pp. 2286-2290

Datar, R.P., Shenkman, R.M., Cateni, B.G., Huhnke, R.L., Lewis, R.S., 2004. Fermentation of Biomass-generated Producer Gas to Ethanol. Biotechnology and Bioengineering, Volume 86(5), pp. 587-594

Demirbas, A., 2009. Hydrogen-rich Gases from Biomass via Pyrolysis and Air-steam Gasification. Energy Sources Part A-Recovery Utilization and Environmental Effects, Volume 31(19), pp. 1728-1736

Gibran, F.R., Surjosatyo, A., Hermawan, A.A., Dafiqurrohman, H., Anggriawan, M.B., Yusuf, N.R., Maarif, S., 2018. Optimization of Fixed Bed Downdraft Reactor for Rice Husk Biomass Gasification using Secondary Air Intake Variation. International Journal of Technology, Volume 9(2), pp. 390-399

Kajita, M., Kimra, T., Norinaga, K., Li, C.Z., Hayashi, J., 2010. Catalytic and Noncatalytic Mechanisms in Steam Gasification of Char from the Pyrolysis of Biomass. Energy Fuels, Volume 24(1), pp. 108-116

Kumar, M., Gupta, R.C., 1994. Influence of Carbonization Conditions and Wood Species on Carbon Dioxide Reactivity of Resultant Wood Char Powder. Fuel Processing Technology, Volume 38(3), pp. 223-233

Kumar, M., Gupta, R.C., Sharma, T., 1992. Influence of Carbonization Temperature on the Gasification of Acacia Wood Chars by Carbon Dioxide. Fuel Processing Technology, Volume 32(1-2), pp. 69-76

Lestari, R., Prasetya, A., Sulistyo, H., Yuliansyah, A.T., 2018. Characterization of Solid Product from Bamboo Waste (Gigantochloa Apus) by Hydrothermal Treatment. AIP Conference Proceedings, Volume 2026, pp. 020067

Mangut, V., Sabio, E., Ganan, J., Gonzales, J.F., Ramizo, A., Gonzales, C.M., Roman, S., AlKassir, A., 2006. Thermogravimetric Study of the Pyrolysis of Biomass Residues from Tomato Processing Industry. Fuel Processing Technology, Volume 87(2), pp. 109-115

Mappapa, I.A., Yuliansyah, A.T., 2018. Solid Biofuel Production from Meranti (Shorea Sp.) Sawdust using Hydrothermal Treatment. Key Engineering Materials, Volume 789, pp. 104-109 
Moilanen, A., Nasrullah, M., Kurkela, E., 2009. The Effect of Biomass Feedstock Type and Process Parameters on Achieving the Total Carbon Conversion in the Large Scale Fluidized Bed Gasification of Biomass. Environmental Progress \& Sustainable Energy, Volume 28(3), pp. 355-359

Parshetti, G.K., Quek, A., Betha, R., Balasubramanian, R., 2014. TGA-FTIR Investigation of Co-combustion Characteristics of Blends of Hydrothermally Carbonized Oil Palm Biomass (EFB) and Coal. Fuel Processing Technology, Volume 118, pp. 228-234

Prins, M.J., Ptasinski, K.J., Janssen, F.J.J.G., 2006. More Efficient Biomass Gasification via Torrefaction. Energy, Volume 31(15), pp. 3458-3470

Rodrigues, M., Walter, A., Faaij, A., 2003. Co-Firing of Natural Gas and Biomass Gas in Biomass Integrated Gasification/Combined Cycle Systems. Energy, Volume 28(11), pp. 1115-1131

Ruksathamcharoen, S., Ajiwibowo, M.W., Chuenyam, T., Surjosatyo, A., Yoshikawa, K., 2018. Effect of Hydrothermal Treatment on Grindability and Fuel Characteristics of Empty Fruit Bunch Derived Hydrochar. International Journal of Technology, Volume 9(6), pp. 12461255

Sridhar, G., Paul, P.J., Mukunda, H.S., 2001. Biomass Derived Producer Gas as a Reciprocating Engine Fuel: An Experimental Analysis. Biomass \& Bioenergy, Volume 21(1), pp. 61-72

Sulaiman, S.A., Atnaw, S.M., Moni, M.N.Z., 2012. Experimental Study on Temperature Profile of Fixed-bed Gasification of Oil-palm Fronds. International Journal of Technology, Volume 3(1), pp. 35-44

Tavasoli, A., Ahangari, M.G., Soni, C., Dalai, A.K., 2009. Production of Hydrogen and Syngas via Gasification of the Corn and Wheat Dry Distiller Grains (DDGS) in a Fixed-bed Micro Reactor. Fuel Processing Technology, Volume 90(4), pp. 472-482

Tijmensen, M.J.A., Faaij, A.P.C., Hamelinck, C.N., van Hardeveld, M.R.M., 2002. Exploration of the Possibilities for Production of Fischer Tropsch Liquids and Power via Biomass Gasification. Biomass \& Bioenergy, Volume 23(2), pp. 129-152

Wei, L.G., Xu, S.P., Liu, J.G., Liu, C.H., Liu, S.Q., 2008. Hydrogen Production in Steam Gasification of Biomass with $\mathrm{CaO}$ as a $\mathrm{CO}_{2}$ Absorbent. Energy \& Fuels, Volume 22(3), pp. 1997-2004

Yin, X.L., Wu, C.Z., Zheng, S.P., Chen, Y., 2002. Design and Operation of a CFB Gasification and Power Generation System for Rice Husk. Biomass and Bioenergy, Volume 23(3), pp. 181-187 